УдК 336.741

\title{
ВПЛИВ ЦИФРОВІЗАЦІЇ НА ТРАНСФОРМАЦІЮ ГЛОБАЛЬНОГО ФІНАНСОВОГО РИНКУ
}

\section{IMPACT OF DIGITALIZATION ON THE TRANSFORMATION OF THE GLOBAL FINANCIAL MARKET}

\author{
Гаркавенко Владислав Олександрович \\ здобувач освітнього ступеня «Магістр», \\ Національний технічний університет України \\ «Київський політехнічний інститут імені Ігоря Сікорського» \\ ORCID: https://orcid.org/0000-0003-0508-594X \\ Грінько Ірина Миколаївна \\ кандидат економічних наук, доцент, \\ Національний технічний університет України \\ «Київський політехнічний інститут імені Ігоря Сікорського» \\ ORCID: https://orcid.org/0000-0002-8948-5686
}

\author{
Harkavenko Vladyslav, Hrinko Iryna \\ National Technical University of Ukraine \\ «lgor Sikorsky Kyiv Polytechnic Institute»
}

\begin{abstract}
У статті розглядається вплив впровадження нових цифррових технологій на розвиток і трансорормацію глобального фрінансового ринку. Досліджується механізм функціонування сучасних інновацій на прикладі FinTech, історію походження терміну, його тлумачення та причини виникнення, оцінюються проблеми та перспективи взаємодії FinTech та світової фрінансової системи. Авторами проаналізовано та систематизовано фрактори, що вплинули на розвиток фрінансових технологій. Робота містить огляд ключових цифрових технологій, що використовуються в сфері фрінансів сьогодні, таких як: мобільні технології, аналіз великих даних, штучний інтелект, цифрові валюти, блокчейн, віртуальна реальність, безконтактні технології, біометричні технології. На основі проаналізованих даних побудовано прогноз розвитку фінтех сегменту і сформовано основні тренди щодо фрінансових технологій.
\end{abstract}

Ключові слова: фрінансовий ринок, фрінтех, блокчейн, цифррові валюти, онлайн-банкінг, необанкінг, кібербезпека.

В статье рассматривается влияние внедрения новых цифровых технологий на развитие и трансорормацию глобального рынка. Исследуется механизм функционирования современных инноваций на примере FinTech, истории происхождения термина, его толковании и причинах возникновения, оцениваются проблемы и перспективы взаимодействия FinTech и мировой финансовой системы. Авторами проанализированы и систематизированы фракторы, повлиявшие на развитие фринансовых технологий. Работа содержит обзор ключевых цифровых технологий, используемых в сфере фринансов сегодня, таких как: мобильные технологии, анализ больших данных, искусственный интеллект, цифровые валюты, блокчейны, виртуальная реальность, бесконтактные технологии, биометрические технологии. На основе проанализированных данных построен прогноз развития фринтех сегмента и сформированы основные тренды по фринансовым технологиям.

Ключевые слова: фринансовый рынок, фринтех, блокчейн, цифровые валюты, онлайн-банкинг, необанкинг, кибербезопасность.

The article considers the impact of the introduction of new digital technologies on the development and transformation of the global financial market. The financial technology industry is gradually becoming an independent intensively developing sector of the modern economy. As the global digital economy is in a position where opportunities and risks are in balance, it is important to identify and assess the impact of technology on the financial market to identify development prospects. To do this, it is necessary to reveal the essence of the concept of "fintech" and explore the history of its development. In the course of the work the works of domestic and foreign scientists on the topic of financial technologies and their impact on the financial market were analyzed. The mechanism of functioning of modern innovations on the example of FinTech, the history of the origin of the term, its interpretation and causes, the problems and prospects of interaction between FinTech and the global financial system are studied. The authors 
analyze and systematize the factors that influenced the development of financial technologies. The paper provides an overview of key digital technologies used in finance today, such as: mobile technology, big data analysis, artificial intelligence, digital currency, blockchain, virtual reality, contactless technology, biometric technology. Based on the analyzed data, the forecast of fintech segment development is built and the main trends in financial technologies are formed. The impact of the COVID-19 pandemic in 2020 on accelerating the transformation of the financial sector with a change of vector on the development of financial technologies has been assessed. The topical problem of forecasting future market prospects and determining winning opportunities for the countries of the world is revealed and investigated. The analysis of the main sources of financing of fintech projects is carried out. Such as venture capital, mergers and acquisitions, and direct investment are highlighted. The share of venture capital as the most popular source of investment is estimated.

Keywords: financial market, fintech, blockchain, digital currencies, online banking, neobanking, cybersecurity.

Постановка проблеми. На даний момент - у вік інорормаційних технологій та комп'ютеризації - цифррова економіка торкається практично кожного аспекту нашого життя. Це і освіта, і щоденне споживання, охорона здоров'я, фрінанси, і навіть фрункціонування урядових структур. Фінансовий ринок не $\epsilon$ винятком. Генерація, зберігання та передача інорормації $є$ одним з основних елементів діяльності фрінансового сектора. Фінансові вимоги та зобов'язання клієнтів відображаються у вигляді бітів даних, платежі та операції здійснюють за допомогою інфрормаційних потоків, а аналіз даних допомагає фрінансовим організаціям есрективніше оцінювати кредитоспроможність позичальників. Це лише частина прикладів, що вказують, наскільки срінансова індустрія ґрунтується на необхідності обробки даних. Відповідно, і пояснює, чому саме фрінансовий сектор один з секторів, в яких найбільше інвестицій спрямовувалося в інфрормаційно-комунікаційні технології.

В результаті індустрія фрінансових технологій поступово перетворюється на самостійний інтенсивно розвиваючий сектор сучасної глобальної економіки. 3'явилося поняття «Fintech» у практичному вжитку надання фрінансових послуг, і стало потужним трендом. Глобальний ринок фрінансових технологій $є$ одним із найбільш швидко зростаючих у світі. Кількість користувачів фрінансових технологій у світі, за експертними оцінками, щороку зростає на $15-20 \%$, відповідно активно сприяє зростанню та проникненню інтернету у світі. Очікується, що ринок зросте до 191840,2 млн. дол. США у 2025 році, і до 325311,8 млн. дол. США у 2030 році [1].

Аналіз останніх досліджень та публікацій. Присвятили чимало досліджень в питаннях розвитку фрінансового ринку 3 урахуванням впливу цифрових технологій відомі науковці та практики: О. В. Борисюк, Л. О. Гаряга, Л. В. Рудич, О. М. Шевченко та інші. Зокрема, дослідженню розвитку «FinTech» технологій присвятили свої праці:
Т. О. Гаврилко, С. М. Шкарлет, М. В. Дубина, О. С. Жук, П. М. Рубанов та інші вчені, які займалися вивченням впливу цифровізації на розвиток глобального фрінансового ринку.

Постановка завдання. Оскільки глобальна цифрова економіка знаходиться в положенні, коли можливості та ризики знаходяться в рівновазі, то важливо визначити і оцінити вплив технологій на фрінансовий ринок для виявлення перспектив розвитку. Для цього необхідно розкрити сутність поняття «фінтех» та дослідити історію його розвитку. Варто зауважити, що пандемія COVID-19 у 2020 році призвела до пришвидшення трансорормації фрінансового сектору зі зміною вектору на розвиток фрінансових технологій. Тому актуальною $€$ проблема прогнозування майбутніх перспектив ринку та визначення виграшних можливостей для країн світу.

Виклад основного матеріалу. Активний розвиток інформаційних технологій поширюється на всі сорери життя. Фінансовий ринок не став винятком - з'явився новий перспективний напрямок FinTech, або срінансові технології. На сьогодні саме ринок фрінансових технологій вважається одним із найактивніше зростаючих. Варто зазначити, що в українській мові відсутнє тлумачення такого поняття як FinTech (або фрінансових технологій), незважаючи нате, що цей термін вже активно використовується протягом кількох років. Згідно із зарубіжними джерелами FinTech (financial technology) це: 1) галузь економіки, що складається з компаній, що використовують технології для надання фрінансових послуг ефективнішим способом, а компанії з цієї галузі, здебільшого, є стартапами, створеними з метою здійснення прориву у вже існуючих фрінансових системах та організаціях, які використовують програмні продукти; 2) сорера дії технічних стартапів, що здійснюють переворот у таких напрямках, як мобільні платежі, перекази грошей, позики, залучення коштів та навіть управління активами [2]; 3) бізнес-напрямок, в основі якого лежить вико- 
ристання програмних товарів надання срінансових послуг [3].

Термін FinTech був введений Силіконовою долиною. Саме там було створено безліч IT-проектів, які пізніше стали чимось на кшталт «акселератора» сучасним фрінтехам. Цим поняттям називають стартапи, які базуються на впровадженні сучасних фрінансових технологій, завдяки яким, фрінансові сервіси стають більш есрективнішими. Столицею FinTech вважається Лондон завдяки його інвестиційним потокам. Перше покоління підривних інновацій у фрінтеху припало на початок 2000-х років. Вони були представлені новими бізнес-моделями, в основі яких лежали інтернет-технології. Першою 3 таких бізнес-моделей стала модель фрінансових агрегаторів (маркетплейсів). Другою - модель онлайн-трейдингу, яка докорінно змінила торгівлю цінними паперами у всьому світі.

Значне зростання популярності фрінтеху почалося в 2008 р., коли світова фрінансова криза змусила фрінансові компанії скорочувати витрати. Це співпало з бурхливим розвитком ринку мобільних технологій, який продовжується і сьогодні. Портативні гаджети надали можливість людині перебувати в кіберпросторі цілодобово, куди поступово переміщуються торгівля, освіта, спілкування, розваги, робочі процеси і т. д. Відповідно, нові умови життя вимагають нових способів поводження 3 фрінансами. Таким чином фрінтех-компанії успішно заповнюють цю нішу. Такі організації, як показує світова практика, що оперативніше традиційних фрінансових організацій реагують на зміни ринку, швидше додають абсолютно нові продукти та послуги. Цільовою аудиторією таких стартапів $€$ нові покоління споживачів, які виросли на цифррових технологіях.

У 2020 році COVID-пандемія спричинила подібні до кризи 2008 року умови, коли поведінка споживачів змінилася, і компанії знову були змушені задуматися про нові шляхи розвитку. Втім, деякі фрінтех-тренди не відчули на собі впливу COVID-19: так, традиційні банки та технологічні компанії продовжують існувати в режимі суперництва-співпраці, конкуруючи між собою та одночасно фрормуючи нові моделі спільної роботи.

У поточній ситуації фрінтех проходить перевірку на міцність: якщо в минулі кризи він лише готувався створити підривні технології або починав пропонувати масові рішення, то зараз упевнено розвинувся і зайняв свої ніші. При цьому поточна криза не пройде безслідно: фрінансовий сектор уже відчув ії̈ вплив. Наприклад, остаточно сорормувався цілко- витий перехід фрінансової сфрери в онлайн, тепер це нова норма. У 2019 році 64\% споживачів використовували два або більше фрінтех-сервіси [4]. Крім того, останні статистичні дані щодо фрінансових технологій свідчать, що пандемія COVID-19 сприяла прискоренню розвитку хмарних сервісів та подібних рішень для галузі. Тому використання фрінтеху буде тільки зростати в найближчі роки.

Чинниками, що активно стимулюють розвиток сектора фрінансових технологій, стали зростання проникнення інтернету в усьому світі, а також процеси цифровізації, що охопили майже всі сфрери людського життя, включаючи і фрінансовий сектор. На рис. 1 відображено рівні проникнення інтернету у ключових регіонах планети на початок 2021 року.

Ключові технології на фрінансовому ринку та їх вплив. На розвиток фрінансового ринку впливає наступне покоління технологій, які безпосередньо пов'язане з Інтернетом. Прикладом таких технологій є: мобільні технології, аналіз великих даних, штучний інтелект, цифрові валюти, блокчейн, віртуальна реальність, безконтактні технології, біометричні технології. Мобільні технології - сукупність мобільних пристроїв та програм, застосування базується на бездротовій комунікації. Інфрраструктура мобільного зв'язку розвивається швидкими темпами. Розширюється географрія присутності мобільного Інтернету та зростає швидкість його роботи. Сприяє цьому і прискорення розвитку ринку мобільних технологій. Рішення стають дедалі більше кросплатформними та багатофрункціональними.

У фрінансовому секторі внаслідок розвитку мобільних технологій виділився окремо напрямок - мобільний банкінг, який передбачає управління банківським рахунком за допомогою мобільних пристроїв. Згідно з прогнозом кількість користувачів онлайн-банкінгів зростатиме наступні 3 роки з темпом $6 \%$ на рік, і до 2024 року досягне відмітки в 2,5 млрд. користувачів по всьому світу [6].

Великі дані - позначення структурованих та неструктурованих даних величезних обсягів, а також технологій їх обробки та використання, методи пошуку необхідної інформації у великих масивах. Джерелами даних виступають різні інтернет-документи, соціальні мережі, транзакції по банківських картках, радіочастотна ідентисрікація, пристрої аудіо- та відеореєстрації тощо. Аналітика великих даних дозволяє фрінансовим організаціям виявляти нових споживчів категорії, створювати максимально персоналізовані продукти та ін. 


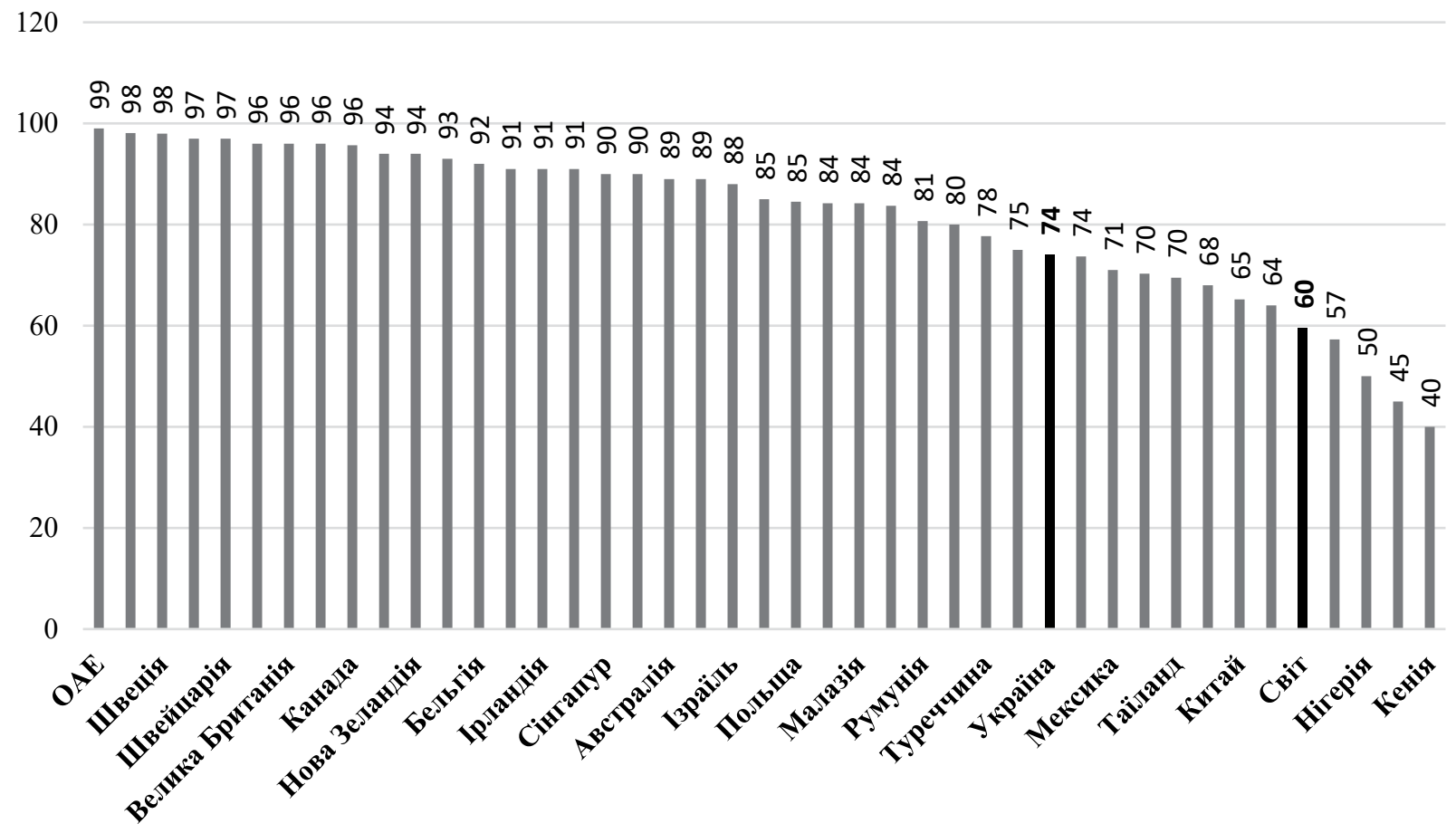

Рис. 1. Проникнення Інтернету в світі, січень 2021, \% Джерело: [5]

Згідно з дослідженням Fintech Future суб'єкти фрінансового ринку очікують від впровадження технологій, пов'язаних 3 аналізом великих даних, такі переваги: збільшення конкурентоспроможності (40\%), оптимізацію витрат (18\%), розширення клієнтської бази (17\%), покращення клієнтського досвіду (15\%) та збільшення частки маржинальності (8\%) (рис. 3) [7].
Штучний інтелект - технології, що дозволяють створювати інтелектуальні машини та програми, здатні виконувати творчі фрункції, які традиційно вважаються прерогативою людини (наприклад, написання музики, літературних творів та ін.). Фінансовим компаніям технології на базі штучного інтелекту дозволяють працювати на випередження та нада-

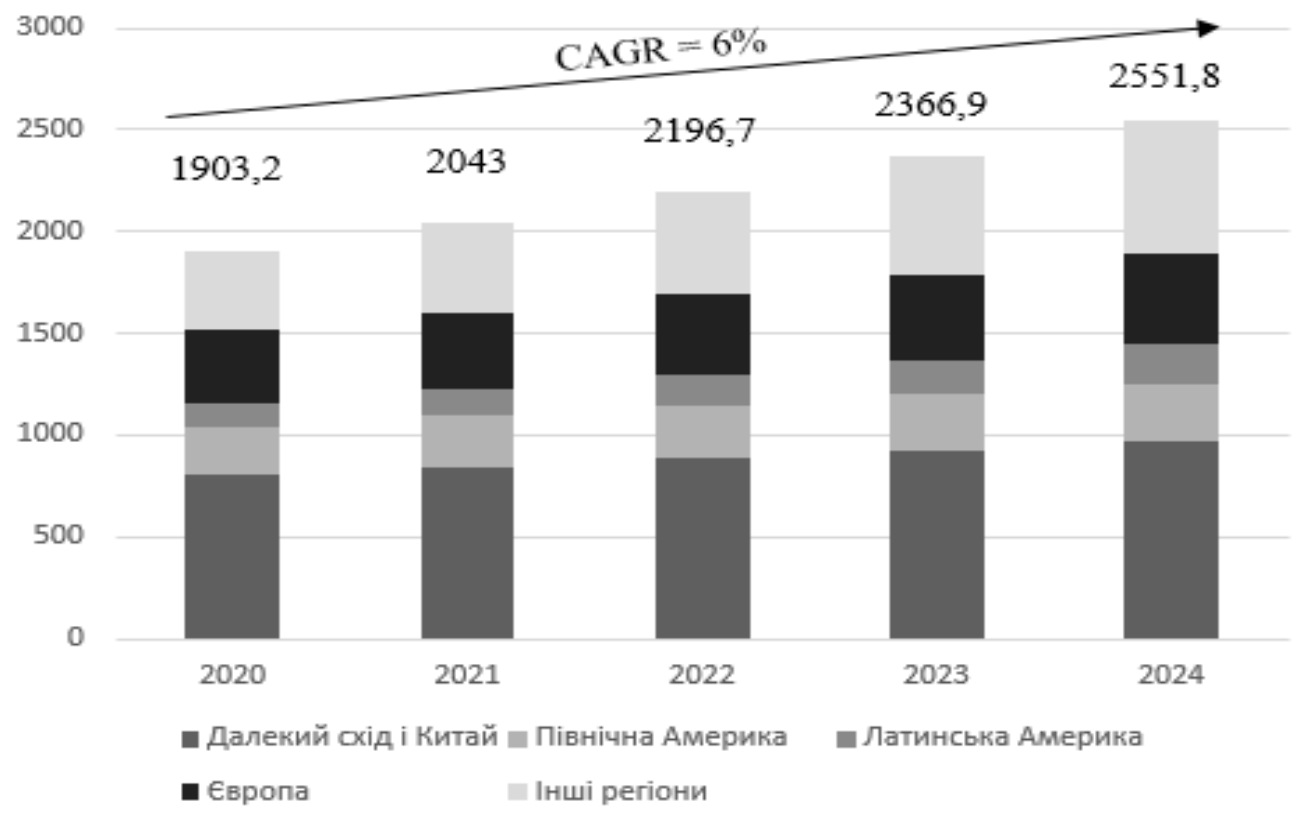

Рис. 2. Прогноз кількості користувачів онлайн-банкінгів, млн. Джерело: побудовано на підставі [6] 


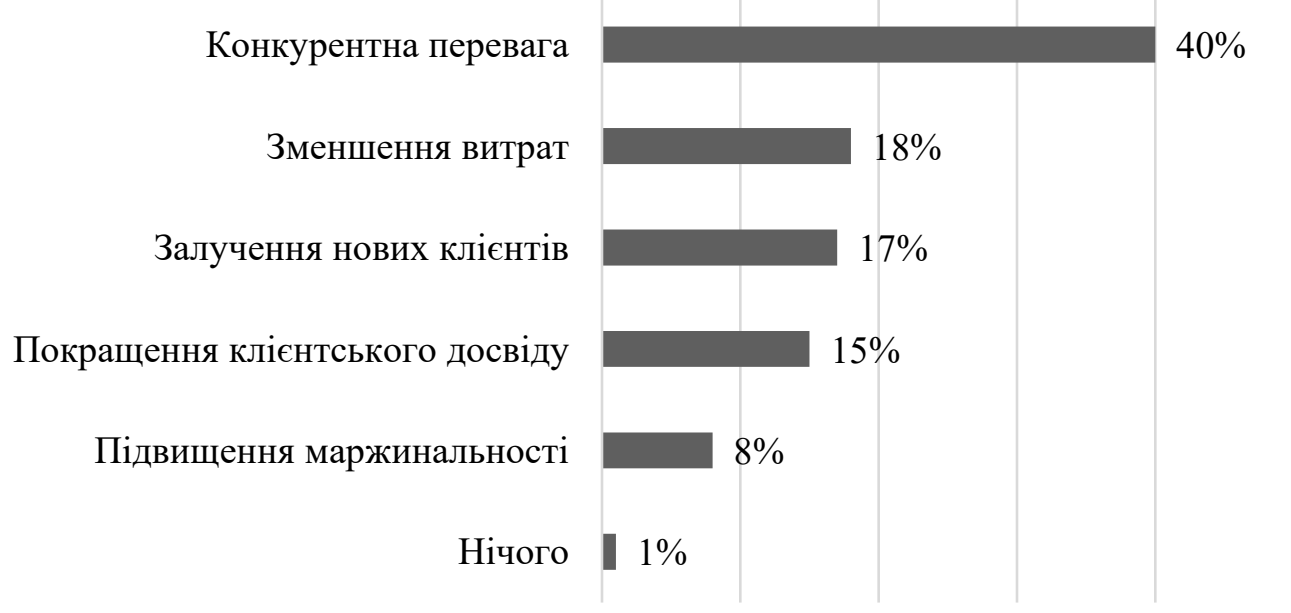

Рис. 3. Результати опитування учасників фрінансового ринку щодо основної очікуваної переваги від аналізу великих даних, \%

Джерело: [7]

вати максимально персоналізований сервіс, при цьому скорочуючи витрати.

За даними Mordor Intelligence, ринкова вартість штучного інтелекту в фрінтех становила 7,91 млрд дол. у 2020 році, і очікується 26,67 млрд дол. до 2026 року при сукупному річному темпі зростання у 23,17\% [8]. Прикладом використання штучного інтелекту в фрінансовому секторі можуть бути: системи для автоматизації управління процесами та внутрішніх валютних операцій, оптимізації торговельної діяльності для покращення персоналізованого банківського досвіду, створення ефективніших заходів для виявлення шахрайства, інфрормування кредитних рішень тощо. Виникли цифрові валюти - це кошти, що не мають матеріального втілення, які можуть використовуватися як фрізичними, так і юридичними особами як повноцінні грошові знаки. Для користування цифровими платіжними засобами не потрібно відкривати рахунок у традиційному банку, достатньо онлайнреєстрації у відповідній платіжній системі.

Сьогодні виділяють два типи циоррових валют - електронні гаманці (наприклад, PayPal, WebMoney, ApplePay та ін.) та криптовалюти (біткоїн, ефріріум, лайткойн та ін.). Але якщо електронні гаманці потрібно поповнювати «традиційними» коштами, то емісія (майнінг), обмін та облік криптовалют заснована на специфічному застосуванні криптографрічних алгоритмів (шифрування). При цьому всі криптовалюти базуються на технології блокчейн (або технології розподіленого реєстру) ланцюжку інформаційних блоків, збудованих у суворій послідовності та за певними прави- лами. Кожен запис містить інфрормацію про історію володіння, що гранично ускладнює можливість фральшування інформації. У найближчі 12-18 місяців прогнозується фрінансування в розмірі понад 425,5 млн. дол. для блокчейн-стартапів у Європі [9]. У світі спостерігається активне зростання фрінтех-проектів на основі технології блокчейн. Деякі країни вже визнали криптовалюти повноцінним засобом платежу та навіть стали розробляти власну державну криптовалюту (наприклад, Японія, OAE). Інші держави обмежили використання криптовалют або повністю заборонили її, вбачаючи у ній загрозу.

Станом на 2021 рік глобальний рівень володіння криптовалютою оцінюється в середньому на рівні 3,9\%, 3 понад 300 мільйонами користувачів криптовалют у всьому світі. А понад 18000 компаній вже приймають криптовалютні платежі. Україна ж займає перше місце в рейтингу власників криптовалют 3 проникненням 12,73\% від загальної кількості населення [10].

Віртуальна реальність - створене технічними засобами середовище, яке транслюється людині за допомогою її можливостей сприйняття інорормації (зір, слух, дотик, нюх тощо). Для створення переконливого комплексу відчуттів комп'ютерних синтез властивостей, відповідно реакції віртуальної реальності реалізується в реальному часі.

Класичні фрінансові організації та фрінтехстартапи активно використовують технології віртуальної та доповненої реальності з метою підвищення якості дистанційного обслуговування та підвищення лояльності клієнтів. 
Наприклад, відкриття повнофункціональних віртуальних відділень, створення сервісів 3 навчання фрінансової грамотності, організація віртуальних розважальних майданчиків для своїх клієнтів та ін. Деякі банки, наприклад, Національний банк Оману, використовує AR, щоб допомогти своїм клієнтам знайти найближчий банкомат або знайти деякі пропозиції під час шопінгу в торговому центрі чи на будьякій вулиці в Омані. Тим часом BNP Paribas пропонує своїм клієнтам досвід віртуальної реальності, який дозволяє їм віртуально отримувати доступ до облікових записів і записів транзакцій, або проводити користувачів через різноманітні та складні етапи покупки нерухомості в режимі віртуальної реальності.

У 2019 році розширена реальність (XR), яка включає доповнену реальність (AR), віртуальну реальність (VR) і змішану реальність (MR), була визнана однією 3 найбільш перспективних тенденцій у сорері фрінтех. Згідно 3 цьогорічним опитуванням, 45\% споживачів, які володіють технологіями, хочуть, щоб їхні банки представляли нові способи спілкування, пов'язані 3 віртуальною реальністю. У той же час 80\% респондентів вважають, що важливо бути піонером у XR-рішеннях [11].

Безконтактні технології - бездротові короткодистанційні технології, що працюють на відстані не більше $10 \mathrm{~cm}$. Інфрормація з об'єктів зчитується за допомогою радіосигналу. Інтегруються сьогодні до смартфонів, планшетів, смарт-годинників, пластикових карт. Що стосується застосування у фрінансовому секторі, то це проведення безконтактних платежів за допомогою пристроїв, як правило, із вбудованим NFC-чіпом - смарторонів, браслетів.

Біометричні технології базуються на біометрії, вимірі унікальних характеристик окремо взятої людини. Йдеться про динамічні (поведінкові) та статичні (фрізіологічні) характеристики. До поведінкових ознак належать голос, жести, хода та ін. До фрізіологічних - відбитки пальців, геометрія обличчя, сітківка ока. У фрінансовому секторі біометрія використовується в системах ідентифрікації та аутентифрікації з метою підвищення безпеки транзакцій, що проводяться.

На думку експертів, впровадження нових технологій сприяє посиленню конкуренції на фрінансових ринках Розширюються та персоналізуються продуктові пропозиції і натомість спрощується доступ до них. Поступово розмиваються межі між самими фрінансовими продуктами та послугами. 3'являються та розвиваються нові гнучкі бізнес-моделі, що дозволяють оперувати у нових ринкових нішах. Наприклад, Р2Р-сервіси стали найважливішою формою нових відносин, що виникли завдяки розвитку фрінтех-індустрії. Інновації також дозволяють збільшувати ефективність бізнесу. За оцінками експертів, вартість супроводу будь-яких транзакцій, пов'язаних із фрінансами, знижується у всьому світі. Нові рішення допомагають суттєво знижувати собівартість залучення та обслуговування клієнтів, оцінювати та попереджати існуючі та нові ризики, знаходити нові джерела доходу та ін. При цьому підвищується прозорість бізнесу. Розподілені системи поступово реструктурують існуючі бізнес-моделі, роблячи їх максимально прозорими.

Прогнозування розвитку ринку фрінансових технологій. Фінтех-ринок складний для комплексної оцінки через його сильну диверсиорікацію та недоступність інтегрованих даних з низки напрямків. Згідно з даними Statista. com, обсяг транзакцій у грошовому вираженні у ключових сегментах сектора активно зростає, збільшуючись у середньому на 22\% на рік і за прогнозами до 2025 року досягне 22 706,97 млн. дол. США (рис. 4) [12].

Одним із показників, що характеризує рівень розвитку фрінтех-ринку, є кількість користувачів срінтех послуг та середня цінність їх транзакцій в грошовому вираженні. Глобальний фрінтех займає лідируючі позиції щодо динаміки свого розвитку, включаючи охоплення кінцевих користувачів, кількість яких постійно зростає на 10\% щорічно [12]. Найбільшу долю в кількості користувачів станом на 2021 рік займає сегмент цифррових платежів - 87\% (близько 5 млрд користувачів). А найбільш швидко зростаючим $€$ сегмент необанкінгу, прогнозний темп росту якого становить $38 \%$ щорічно до 2025 року (рис. 5) [12]. Обсяг транзакцій в грошовому вимірі найвищим $€$ в сегменті альтернативних фрінансів. Альтернативні фрінанси ж за прогнозами мають найшвидший темп зростання до 2025 року (рис. 6) [12]. Альтернативні фрінанси включають в себе операції 3 криптовалютами. Їх популяризація в суспільстві пояснює найвищий рівень обсягу транзакцій та темп зростання.

Основними джерелами фрінансування фрінтех-проектів $€$ венчурний капітал, угоди злиття та поглинання, а також прямі інвестиції. Тут варто відзначити, що у стартапів користуються популярністю альтернативні інструменти залучення фрінансування: краудорандінг, краудінвестінг, Р2В-кредитування, онлайн-фракторинг. Але переважає саме венчурне фрінансування. За оцінкою McKinsey, 


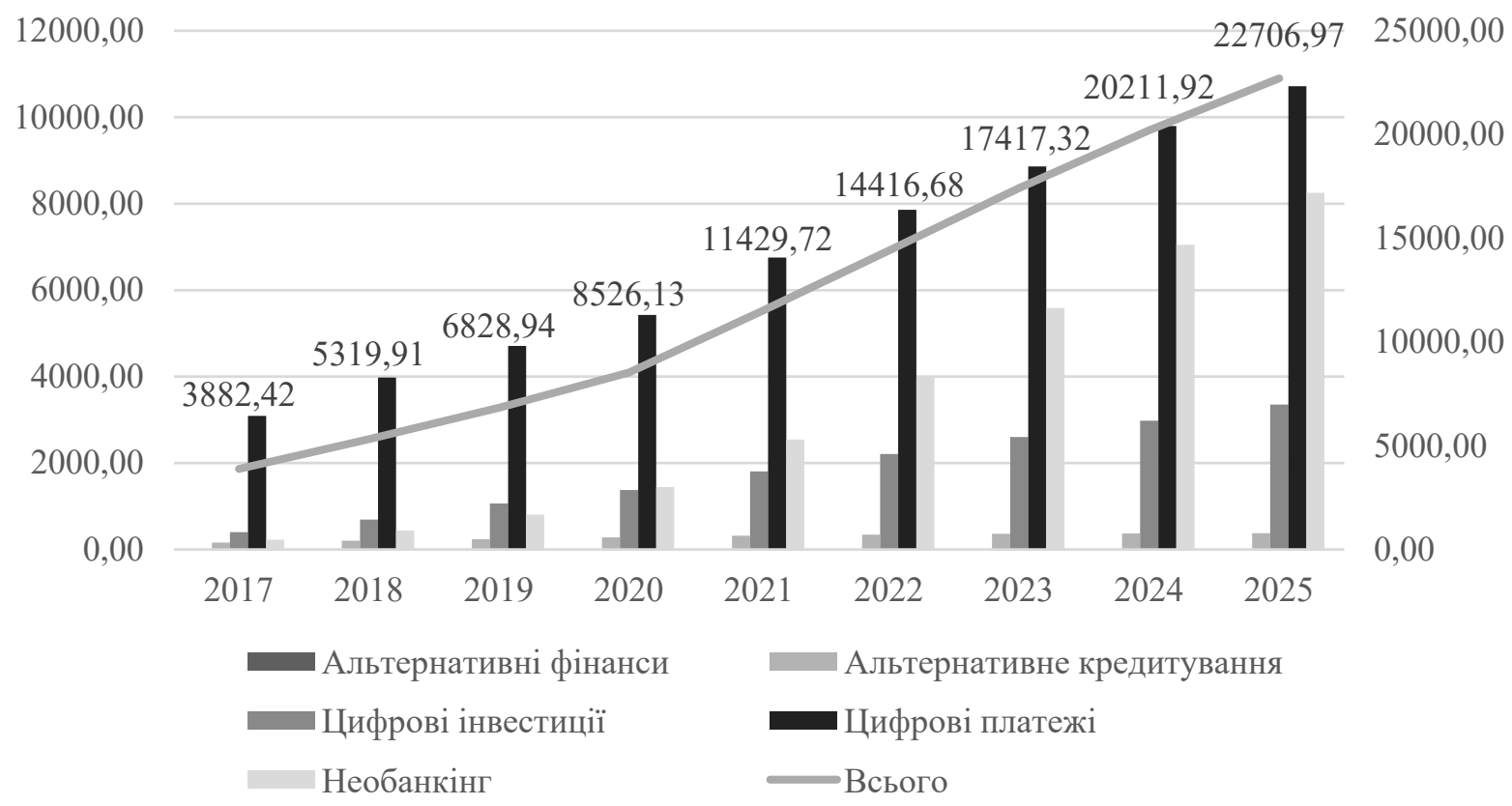

Рис. 4. Обсяг транзакцій у грошовому вираженні в сегменті фрінансових технологій, млн. дол. США

Джерело: побудовано на основі [12]

його частка у загальному обсязі фрінансування становить понад 70\%. Пік залучення інвестицій у фрінтех-компанії припав на 2018-2019 рр. У 2020 році був спад фрінансування, пов'язаний з глобальною кризою у зв'язку з COVID пандемією.
У першій половині 2021 року обсяг інвестицій досягнув рівня в 98 млрд дол. США, що майже дорівнює повному 2020 року. Тому за прогнозами інвестиції в фрінтех-компанії за весь 2021 рік зростуть на 63\%, порівняно з 2020 роком, але все ж не перевищуватимуть обсягів 2019 року [13].

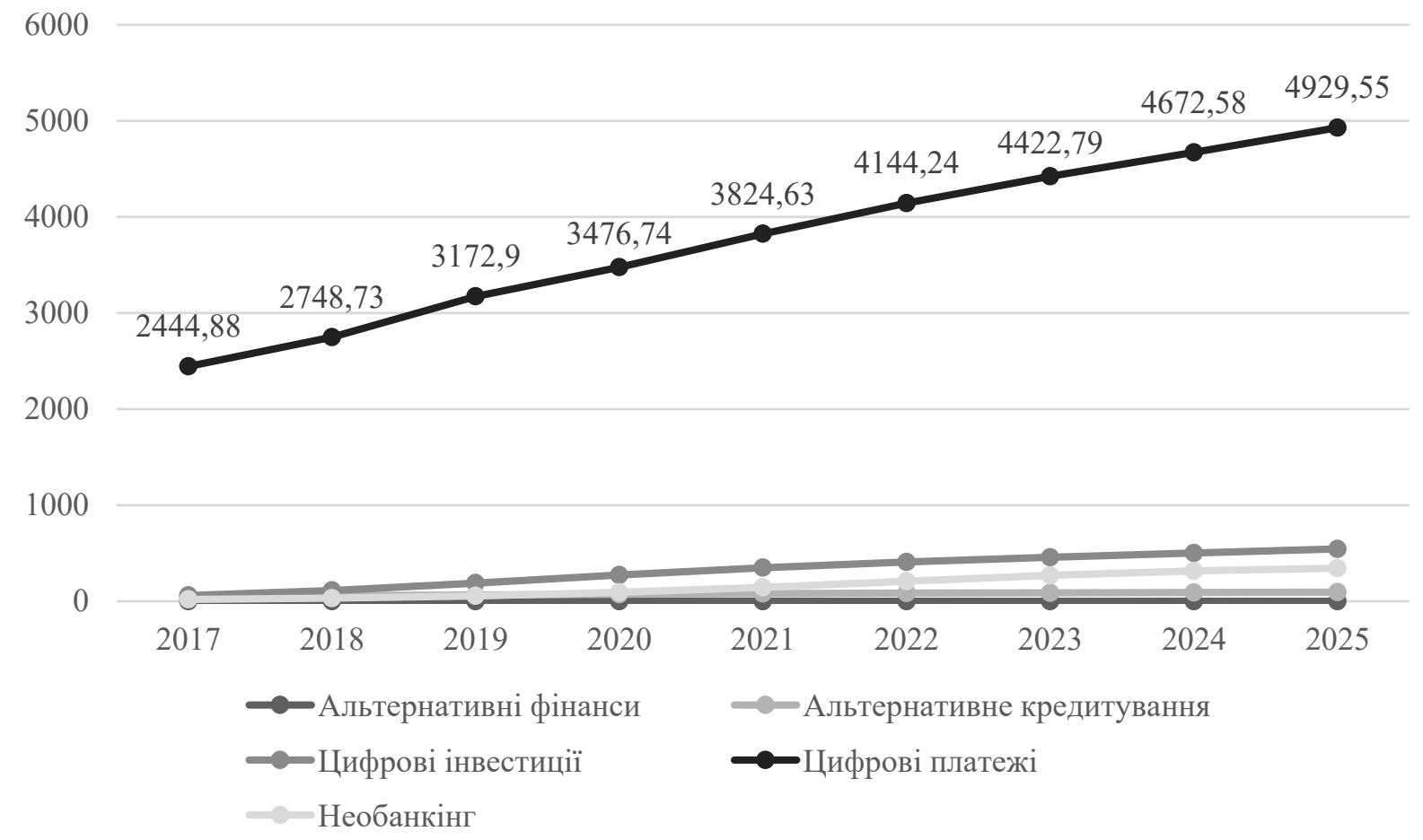

Рис. 5. Кількість користувачів в сегменті фрінансових технологій, млн. Джерело: побудовано на підставі даних [12] 


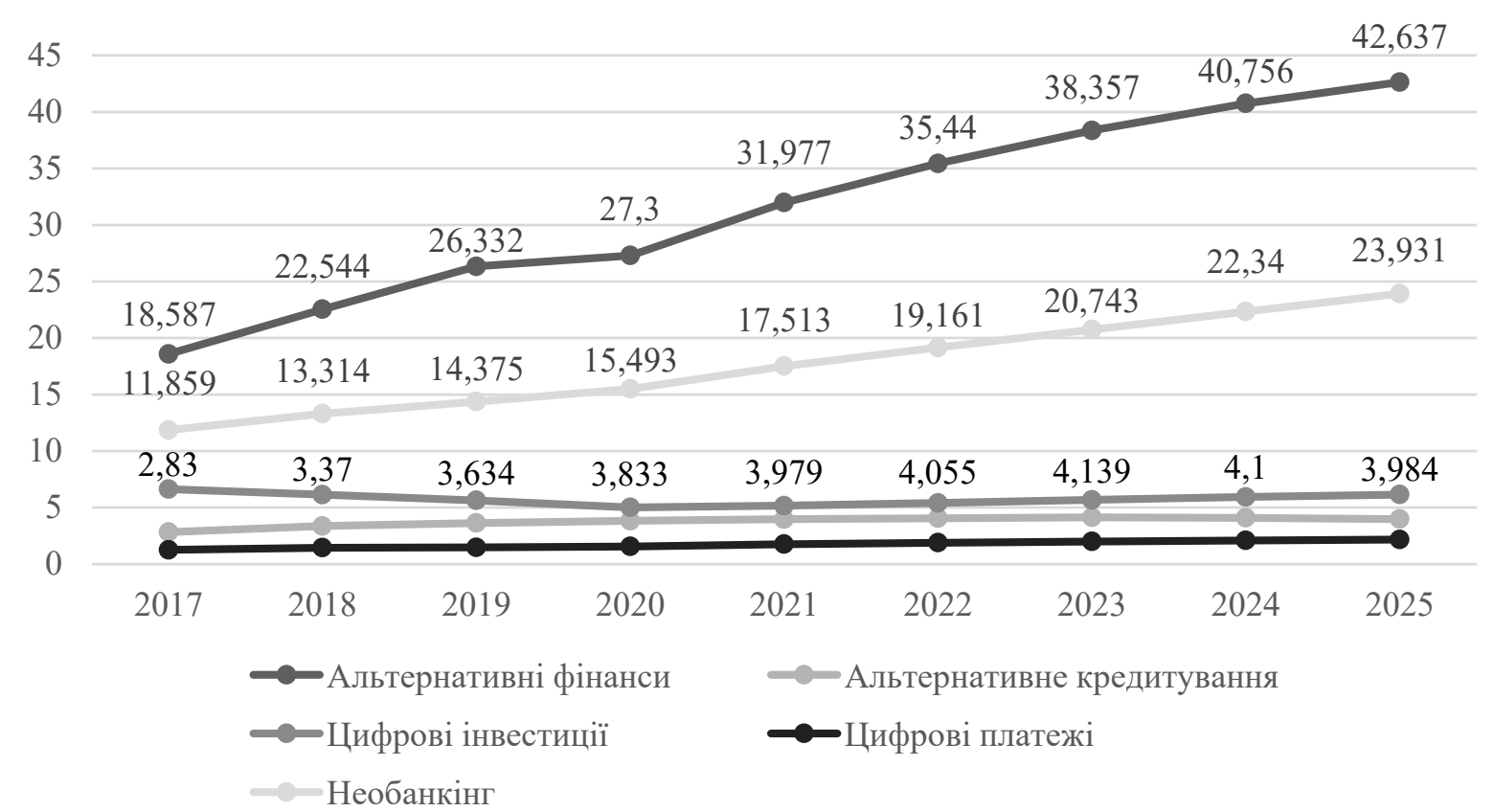

Рис. 6. Середній обсяг транзакції на одного користувача в сегменті фінансових технологій, дол. США

Джерело: побудовано на основі статистики [12]

Висновки. Протягом першої половини 2021 року бачимо, що інтерес до фрінтех у більшості регіонів світу значно виріс. До кінця другої половини року, очікується, що цей імпульс продовжиться. Основними трендами щодо фрінансових технологій у 2021 році виділяють: крипто-екосистеми продовжуватимуть бути у фокуусі інвесторів. Особливо популярними стають NFT; кібербезпека набуде ще більшого значення враховуючи зростання кількості цифррових транзакцій і подальше зростання кібератак та програм-вимагачів, кібербезпека $є$ сорерою уваги інвесторів, особливо корпоративних; наберуть популярності В2В послуги у підсекторах фрінтех; зросте кількість партнерств великих фрінансових і технічних компаній.

$$
250
$$$$
200
$$$$
150
$$$$
100
$$$$
50
$$$$
0
$$

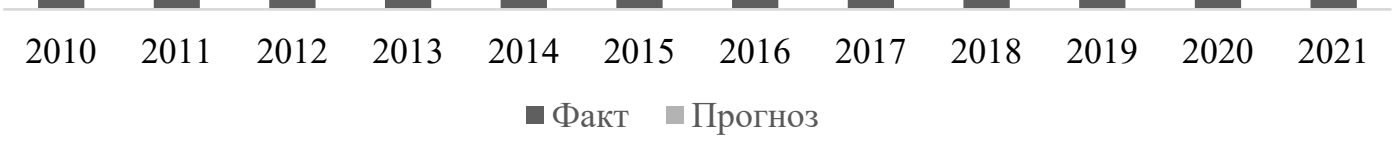

Рис. 7. Загальна вартість інвестицій у фінтех-компанії, млрд дол. США Джерело: побудовано на основі [13] 


\section{СПИСОК ВИКОРИСТАНИХ ДЖЕРЕЛ:}

1. Глобальний ринок Fintech. The Business Research Company. 2021. URL: https://www.thebusinessresearchcompany.com/report/fintech-market

2. Fintech Definition, Fintech Weekly. URL: https://www.fintechweekly.com/fintech-definition

3. Дж. Мунк. Що таке фінтех і чому це має значення для всіх підприємців. 2015. URL: https://www.hottopics.ht/ stories/finance /what-is-fintech-and-why-it-matters/

4. Індекс EY Global Fintech. Компанія EY. 2019. URL: https://www.ey.com/en_us/news/2019/06/ey-globalfintech-adoption-index-finds-over-half-64-of-global-consumers-use-fintech

5. Digital 2021: найновіша думка про «стан цисрових технологій». «Ми соціальні». 2021. URL: https://wearesocial.com/uk/blog/2021/01/digital-2021-the-latest-insights into-the-state-of-digital/

6. Кількість активних користувачів онлайн-банкінгу в усьому світі у 2020 році з прогнозами з 2021 по 2024 рік, за регіонами. Statista. URL: https://www.statista.com/statistics/1228757/online-banking-users-worldwide

7. Сила аналізу даних у фінтех-рішень. Fintech Future. 2021. URL: https://www.fintechfutures.com/ files/2021/03/February-Data-Analytics-report-v4.pdf

8. Al на ринку фрінансових технологій - зростання, тенденції, вплив COVID-19 та прогноз. URL: https://www.mordorintelligence.com/industry-reports/ai-in-fintech-market

9. Холл К. Прогноз: інвестиції у фрінансові послуги з використанням блокчейну готові до зростання у 2021 році. 2021. URL https://news.crunchbase.com/news/forecast-investment-in-financial-services-usingblockchain-poised-for-growth-in-2021

10. Глобальне прийняття криптовалют. URL: https://triple-a.io/crypto-ownership/

11. Глобальний погляд на банківську індустрію, Accenture. URL: https://www.accenture.com/us-en/industries/ banking-index

12. Цисррові ринки: FinTech. Statista. URL: https://www.statista.com/outlook/dmo/fintech/worldwide\#transaction-value

13. Загальна вартість інвестицій у фінтех-компанії по всьому світу з 2010 по I півріччя 2021 року. Statista. URL: https://www.statista.com/statistics/719385/investments-into-fintech-companies-globally/

\section{REFERENCES:}

1. Fintech global market (2021) The Business Research Company. Available at: https://www.thebusinessresearchcompany.com/report/fintech-market

2. Fintech Definition, Fintech Weekly. Available at: https://www.fintechweekly.com/fintech-definition

3. J. Munch (2015) "What is fintech and why does it matter to all entrepreneurs". Available at: https://www.hottopics.ht/stories/finance /what-is-fintech-and-why-it-matters/

4. EY Global Fintech adoption index (2019) EY Company. Available at: https://www.ey.com/en_us/news/2019/06/ ey-global-fintech-adoption-index-finds-over-half-64-of-global-consumers-use-fintech

5. Digital 2021: The latest insights into the 'State of Digital' (2021) We are socials. Available at: https://wearesocial.com/uk/blog/2021/01/digital-2021-the-latest-insights-into-the-state-of-digital/

6. Number of active online banking users worldwide in 2020 with forecasts from 2021 to 2024, by region. Statista. Available at: https://www.statista.com/statistics/1228757/online-banking-users-worldwide/

7. The Power of Data Analytics in FinTech Solutions (2021) Fintech Future. Available at: https://www.fintechfutures.com/files/2021/03/February-Data-Analytics-report-v4.pdf

8. Al in Fintech Market - growth, trends, COVID-19 impact, and forecast. Available at: https://www.mordorintelligence.com/industry-reports/ai-in-fintech-market

9. Hall C. (2021) Forecast: Investment In Financial Services Using Blockchain Poised For Growth in 2021. Available at: https://news.crunchbase.com/news/forecast-investment-in-financial-services-using-blockchain-poisedfor-growth-in-2021

10. Global crypto adoption. Available at: https://triple-a.io/crypto-ownership/

11. Global banking industry outlook, Accenture. Available at: https://www.accenture.com/us-en/industries/ banking-index

12. Digital Markets: FinTech. Statista. Available at: https://www.statista.com/outlook/dmo/fintech/worldwide\# transaction-value

13. Total value of investments into fintech companies worldwide from 2010 to 1 st half 2021 . Statista. Available at: https://www.statista.com/statistics/719385/investments-into-fintech-companies-globally 